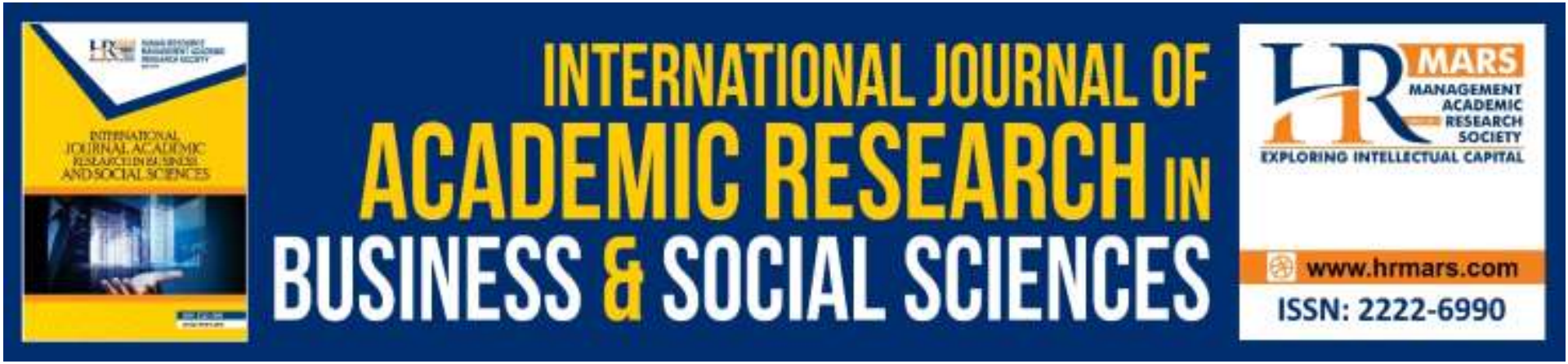

\title{
Teacher's Perception on Computational Thinking Concept
}

\section{Nik Hazimin Nik Hashim, Hazrati Husnin}

To Link this Article: http://dx.doi.org/10.6007/IJARBSS/v9-i11/6718

DOI: 10.6007/IJARBSS/v9-i11/6718

Received: 12 September 2019, Revised: 16 October 2019, Accepted: 12 November 2019

Published Online: 26 November 2019

In-Text Citation: (Hashim, \& Husnin, 2019)

To Cite this Article: Hashim, N. H. K., \& Husnin, H. (2019). Teacher's Perception on Computational Thinking Concept. International Journal of Academic Research Business and Social Sciences, 9(11), 1536-1546.

Copyright: (C) 2019 The Author(s)

Published by Human Resource Management Academic Research Society (www.hrmars.com)

This article is published under the Creative Commons Attribution (CC BY 4.0) license. Anyone may reproduce, distribute, translate and create derivative works of this article (for both commercial and non-commercial purposes), subject to full attribution to the original publication and authors. The full terms of this license may be seen

at: http://creativecommons.org/licences/by/4.0/legalcode

Vol. 9, No. 11, 2019, Pg. 1536 - 1546

http://hrmars.com/index.php/pages/detail/IJARBSS

JOURNAL HOMEPAGE

Full Terms \& Conditions of access and use can be found at http://hrmars.com/index.php/pages/detail/publication-ethics 


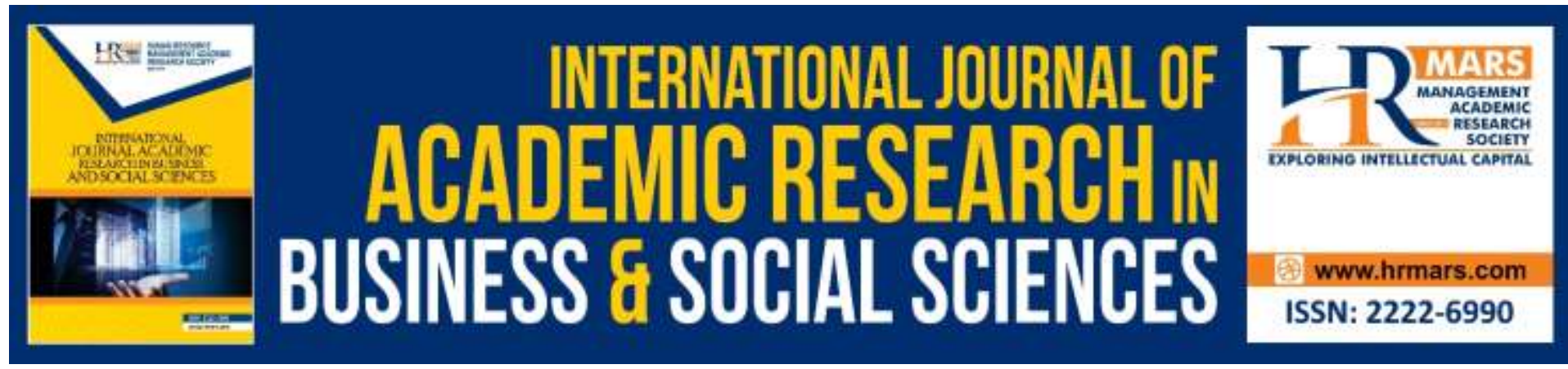

\title{
Teacher's Perception on Computational Thinking Concept
}

\author{
Nik Hazimin Nik Hashim \\ State Education Department, Negeri Sembilan, Malaysia \\ Hazrati Husnin \\ Faculty of Education, Universiti Kebangsaan Malaysia, Malaysia
}

\begin{abstract}
This study was conducted to investigate teachers' perception towards computational thinking skills that being integrated into Malaysia's school syllabus. An adapted survey developed based on Technology Acceptance Model was used to identify teachers' perceived usefulness and perceived ease of use on the integration of computational thinking in teaching and learning, teachers' attitude towards computational thinking skills and their behaviour intention to integrate the skills during teaching and learning. 294 participating primary school teachers from one state in southern region of Malaysia completed the survey and Spearman correlation test was used to analyse the survey data. This study reveals that teachers still have low understanding of the concept of computational thinking after two years of its implementation in curriculum. The findings also reveal that there is a positive correlation between teacher's perceived usefulness of integrating computational thinking skills and teacher's behaviour intention, and teacher's attitude towards computational thinking skills and teacher's behaviour intention. Meanwhile, there is a negative correlation between teacher's perceived ease of use and teacher's behaviour of integrating computational thinking in teaching and learning as a result of misconceptions on computational thinking experienced by the teachers.
\end{abstract}

Keywords: Computational Thinking (CT), Primary School Teachers, Teaching and Learning, Teacher's Perception, Technology Acceptance Model.

\section{Introduction}

In line with technology evolvement and the need to embrace the challenge of industrial revolution 4.0, the focus of education now is on science and technology and its integration in classroom (Rabah, 2016). This raised question of how the current curriculum can support student's development to prepare them in the fast-changing world (Bennett, Maton, \& Kervin, 2008; Guzdial, 2008). Computational thinking (CT), is a problem-solving skill that need to be acquired by everyone to embrace the challenge in the 21st century. CT emphasise on thinking skills which is one of the components in the 21st century skills (Azman, Arsat, \& Mohamed, 2018; Kafai \& Burke, 2013). Thus, integrating CT in school syllabus is equally important to reading, writing and counting skills (Wing, 2006). 
Nevertheless, adapting CT and implementing it in teaching and learning in school is not an easy task. Many measures needed to be taken into account especially to decide on appropriate teaching method to deliver CT concept to students effectively (Viadero, 2007). Knowing the importance of CT skills, Malaysia Ministry of Education (MOE) began introducing CT concepts in current school syllabus emphasising on integrating CT skills in the process of problem solving, logical thinking and lifelong learning skills (Kementerian Pendidikan Malaysia, 2016). In conjunction to that, there was also initiative to provide continuous professional development for teacher in regard to CT training by Malaysian Digital Economic Corporation. Before full implementation of CT in school's curriculum, a preliminary study of teachers' perceptions towards CT in Malaysia showed that the teachers' understanding of CT was at low level (Ling, Saibin, Labadin, \& Aziz, 2017). This is due to the lack of teachers attending training on CT. After two years of implementation of CT in school's curriculum and the training initiative provided to teachers in Malaysia, it is not known how far the teachers have implemented CT skills in their teaching and learning as expected. Although studies showed that teachers competences on CT can be improved in a short period of time through training (Bower, Wood, Lai, Howe, \& Lister, 2017), the actual impact is unknown. Therefore, this study intends to investigate the after-effect after the training initiative, looking at the understanding and perception of teachers in primary school towards CT concepts. This study also aimed to identify issues and misconceptions encountered by the teachers after implementing $\mathrm{CT}$ in teaching and learning.

\section{Literature Review}

\section{Computational Thinking}

CT is defined as a problem-solving approach that can be used in all field to produce solution for a new problem (Barr \& Stephenson, 2011). According to Denning (2009) CT adopt the approach of computer science concept in solving problem. CT skills are one of the problemsolving skills that suggest that a problem can be formulated by adopting computer programming concepts such as decomposition, abstraction and pattern recognition. CT is not just related to computer programming (Wing, 2006), but it is also a basic life skill needed by everyone (Denning, 2009; Lee et al., 2011). In general, there are two main approaches that can be adopted by teachers in teaching CT i.e. via plugged in and unplugged activity. Many studies had shown the benefits of using plugged in tools such as Scratch and LEGO ${ }^{\circledR}$ WeDo $^{\circledR}$ 2.0 to teach CT (Basogain, Olabe, Olabe, \& Rico, 2018; Chalmers, 2018; Grover \& Pea, 2013). Meanwhile, for teachers who have limited access to plugged in tools, they can choose to adopt unplugged activity. Unplugged activities have also been effectively proven in teaching CT skills. See example (Brackmann et al., 2017; Conde et al., 2017). Regardless of using unplugged or plugged in as medium to teach $\mathrm{CT}$, there seemed to be inadequate discussion on teachers' experience, practice and how did they come about to adopt and adapt CT.

\section{Integration of Computational Thinking in Malaysia}

CT is part of the vision stated in Malaysia Education blueprint 2013-2020 (Azman et al., 2018). Unlike other developing countries that had integrated CT in education, CT was relatively new in Malaysia. In order to stay relevant and competent in the era of fourth industrial revolution, it has become the intention of the Ministry of Education to ensure every Malaysian youth is exposed to digital technology and produce future digital makers. Therefore, many skills are crucial in order to better equip them to face the challenges. CT skills are important and need to be instilled at early age (Wing 2006). In Malaysia, children have been introduced to 
computer in school as early in year 1 . The children were taught basic computer knowledge and its application (Kementerian Pendidikan Malaysia, 2014). Realizing the importance of developing problem solving and thinking skills among Malaysia, CT was integrated across syllabus in all subjects from primary Year 1 to form 1 secondary school in 2017. As stated earlier, since CT is still relatively new in Malaysia, there are possibilities of misconception of CT that might hinder the teachers from teaching CT effectively (Cheah, 2018). The transition of teaching and learning process experienced by the teachers i.e. to adopt a different school of thought from the one that they were used to was not known. As such, teachers not only need to be prepared with enough knowledge and understanding of CT concept and skills, but teachers also need to have readiness towards CT and self-confidence to embrace the challenges (Rahayu \& Osman, 2019). Therefore, it is crucial to understand how teachers implement CT in their teaching and learning, and what are the challenges they have experienced in order to understand what more needed to be done to improve CT practice among primary school teachers in Malaysia context.

\section{Technology Acceptance Model (TAM)}

Technology Acceptance Model (TAM) was introduced by Davis (1989) where its primary focus is to predict users' response towards technology based on two factors i.e. (Perceived Usefulness) and (Perceived Ease of Use). Davis define Perceived Usefulness (PU) as "the degree to which a person believes that using a particular system would enhance his or her job performance". Meanwhile Perceived Ease of Use was defined as "the degree to which a person believes that using a particular system would be free from effort". Although TAM being used a lot in studies related to technology acceptance, TAM also being used in other studies to investigate relationship between users and new skills that does not involve technology physically. For example, a study by Durodolu (2016) used TAM to investigate the relationship between users and information literacy skills. In the context of this study, Perceived Usefulness refers to whether the teachers see CT is useful in problem solving. Meanwhile, Perceived Ease of Use refers to whether the teachers find CT easy to be use or integrated in teaching and learning. Therefore, to determine teachers' perception and acceptance of CT, the TAM model will be used in this study.

\section{Methodology}

This study used a survey as methodology to investigate:

What is the level of teachers' understanding on the concept of CT?

What is the level of teachers' perception towards integrating CT in teaching and learning? What are the misconceptions experienced by the teachers in integrating $\mathrm{CT}$ in teaching and learning?

The survey was adapted from (Ling et al., 2017). 42 schools from seven district of a states in southern region of Malaysia were chosen randomly. Permission to conduct study at these schools were obtain from Ministry of Education. Questionnaires were distributed via mail for school without internet access and email for school with internet access. There are three sections in the questionnaire. The first section consists of seven item which is to identify teachers' understanding on the CT concepts.

The second section of the questionnaire was intended to identify teachers' perception towards CT and their tendency to integrate CT skills in teaching and learning. The items in 
this section was developed to identify teachers' acceptance towards CT and integrating CT in teaching and learning. Figure 1 illustrate the model of this study. The items were developed based on construct: teachers' perceived usefulness of CT (PU), perceived ease of use of CT $(\mathrm{PE})$, attitude towards $C T(A)$, and behaviour intention to use $C T$ in teaching and learning $(\mathrm{BI})$.

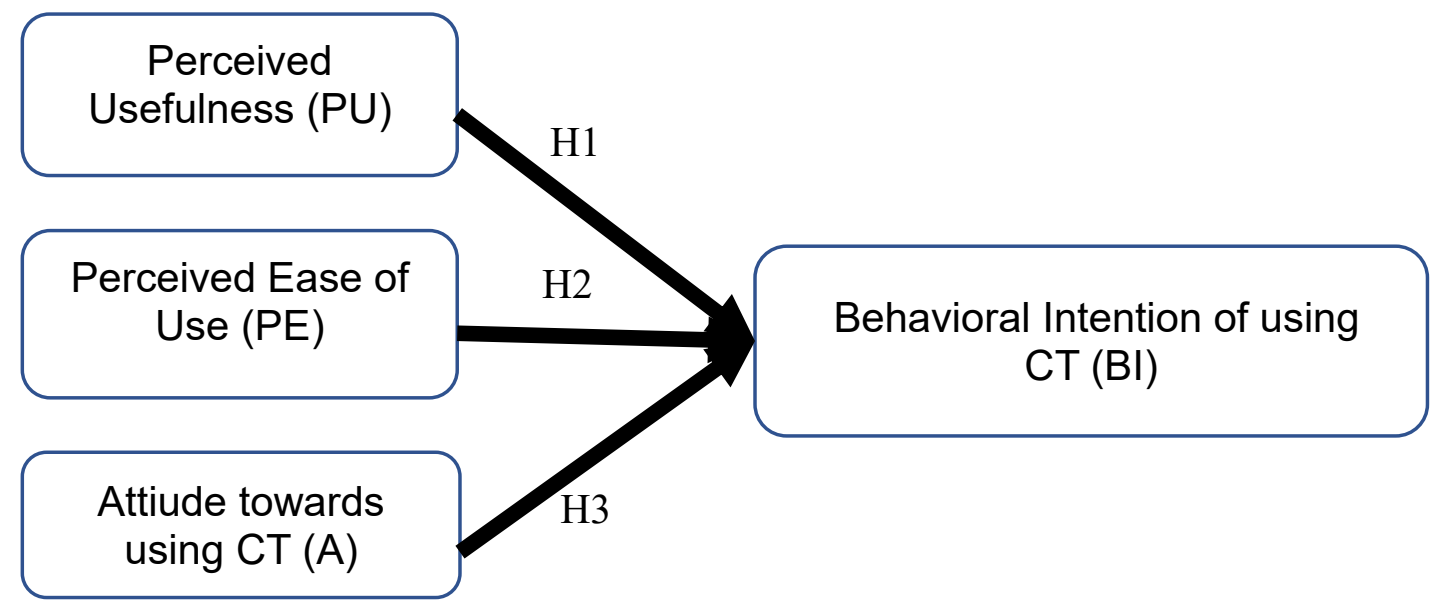

Figure 1: Model of this study

This study hypothesised that

H1: Teachers' perceived usefulness on CT concepts influence the teachers' behaviour intention of using $\mathrm{CT}$ in teaching and learning.

H2: Teachers' perceived ease of use on CT concepts integration influence teachers' behaviour intention of using $\mathrm{CT}$ in teaching and learning.

H3: Teachers' attitude towards CT influence teachers' behaviour intention of using CT in teaching and learning.

The questionnaire consists of four items for PU (Perceived Usefulness) construct, three items for PE (Perceived Ease of Use) construct, four items for A (Attitude towards CT) construct, and two items for behaviour Intention (BI). Five-point Likert scale was used in the questionnaire. The summary of construct and item used in the questionnaire is describe in Table 1.

Table 1: List of construct and item

\begin{tabular}{|l|l|l|}
\hline \multicolumn{2}{|c|}{ Construct } & \multicolumn{1}{c|}{ Item } \\
\hline \multirow{3}{*}{$\begin{array}{l}\text { Perceived } \\
\text { usefulness }\end{array}$} & PU1 & Computational Thinking skills are essential in everyday life \\
\cline { 2 - 4 } & PU2 & CT involves higher order thinking skills \\
\cline { 2 - 3 } & PU3 & Computational thinking involves problem solving skills. \\
\cline { 2 - 3 } & PU4 & $\begin{array}{l}\text { Computational Thinking Skills will benefit one's career } \\
\text { achievements. }\end{array}$ \\
\hline $\begin{array}{l}\text { Perceived ease } \\
\text { of use }\end{array}$ & PE1 & $\begin{array}{l}\text { The addition of Computational Thinking components to the } \\
\text { curriculum will not interfere my teaching and learning process. }\end{array}$ \\
\cline { 2 - 3 } & PE2 & $\begin{array}{l}\text { The addition of Computational Thinking components to the } \\
\text { curriculum will not add to my workload. }\end{array}$ \\
\hline
\end{tabular}




\begin{tabular}{|l|c|l|}
\hline \multirow{2}{*}{$\begin{array}{l}\text { Attitude } \\
\text { towards CT }\end{array}$} & PE3 & $\begin{array}{l}\text { The addition of Computational Thinking components to the } \\
\text { curriculum does not affect the time spent preparing and } \\
\text { teaching and learning }\end{array}$ \\
\cline { 2 - 3 } & A22 & $\begin{array}{l}\text { I'm ready to learn any new instruments / methods / } \\
\text { technologies introduced for teaching and learning } \\
\text { Computational Thinking }\end{array}$ \\
\hline $\begin{array}{l}\text { Ilike the integration of the concept of Computational Thinking } \\
\text { in the new curriculum. }\end{array}$ \\
\hline Intention to use & B11 & \begin{tabular}{l} 
I'm interested to learn more about Computational Thinking. \\
\cline { 2 - 3 } I plan to get involved in teaching and learning related to \\
Computational Thinking
\end{tabular} \\
\hline
\end{tabular}

The data was analysed using SPSS based on alpha Cronbach and Spearman correlation. Alpha Cronbach was used to measure the strength of correlation of each item within each construct. Spearman correlation was used to analyse the correlation between PU ?BI, PE ? $\mathrm{BI}$ dan $\mathrm{A}$ 回 $\mathrm{BI}$.

\section{Findings and Discussion}

Respondent Demographic

The study involved 294 respondents consisting of 65 male teachers and 229 female teachers from primary schools in Negeri Sembilan. The demographic information of the respondents is shown in Table 2 and Table 3 . Table 3 shows that majority of respondents are Degree holders $(83 \%), 7.5 \%$ are Teacher Certificate holders, followed by Diploma (4.8\%), Master $(4.4 \%)$ and $0.3 \%$ with other related academic qualifications.

Table 2: Gender of respondent

\begin{tabular}{llll}
\hline & No & Percentage & $\begin{array}{l}\text { Total } \\
\text { Percentage }\end{array}$ \\
\hline Male & 65 & 22.1 & 22.1 \\
Female & 229 & 77.9 & 100.0 \\
Total & 294 & 100.0 & \\
\hline
\end{tabular}

Table 3: Education level

\begin{tabular}{lll}
\hline & No & Percentage \\
\hline Teacher Certificate & 22 & 7.5 \\
Diploma & 14 & 4.8 \\
Degree & 244 & 83.0 \\
Master & 13 & 4.4 \\
Others & 1 & 0.3 \\
\hline
\end{tabular}

What is the level of teachers' understanding on the concept of CT?

Table 4 showed $75.9 \%$ did not attend any training program related to computer programming. In table 5 showed $85.7 \%$ respondent did not attend any training program related to computational thinking. 
Table 4: Percentage of respondent attend computer programming training

\begin{tabular}{|c|c|c|c|}
\hline & No & Percentage & $\begin{array}{l}\text { Total } \\
\text { Percentage }\end{array}$ \\
\hline Never attended & 223 & 75.9 & 75.9 \\
\hline Attended & 71 & 24.1 & 100.0 \\
\hline Total & 294 & 100.0 & \\
\hline & No & Percentage & $\begin{array}{l}\text { Total } \\
\text { Percentage }\end{array}$ \\
\hline Never attended & 252 & 85.7 & 85.7 \\
\hline Attended & 42 & 14.3 & 100.0 \\
\hline Total & 294 & 100.0 & \\
\hline
\end{tabular}

Table 6 showed 50.3\% respondent were not sure about CT concept, 34\% respondent understood about CT concept, and $15.7 \%$ respondent have low understanding about CT concept.

Table 6: Summary of teachers' respondent on CT concept

\begin{tabular}{llll} 
& No & Percentage & $\begin{array}{l}\text { Total } \\
\text { Percentage }\end{array}$ \\
\hline Strongly Disagree & 9 & 3.1 & 3.1 \\
Do Not Agree & 37 & 12.6 & 15.6 \\
Not Sure & 148 & 50.3 & 66.0 \\
Agree & 97 & 33.0 & 99.0 \\
Strongly Agree (5) & 3 & 1.0 & 100.0 \\
Total & 294 & 100.0 & \\
& Min & \multicolumn{2}{c}{3.1633} \\
\hline
\end{tabular}

What is the level of teachers' perception towards integrating CT in teaching and learning? To identify teachers' perceptions, statistical analysis was performed to assess the reliability and validity of all items by calculating Cronbach's alpha, followed by testing the TAM model by evaluating how much each variable contributed to the coefficient. All constructs showed alpha values greater than 0.7 except for PE. However, according to Di lorio (2005), though the values were $<0.7$, it should not be the only standard used to assess reliability. The lower alpha value could demonstrate higher interrelatedness among items over a short scale. Therefore, the alpha value for PE in this study is accepted. 
Table 7: Construct reliability

\begin{tabular}{ll}
\hline Construct & Alfa Cronbach value \\
\hline Perceived Usefulness of CT (PU) & 0.781 \\
Perceived Ease of Use of CT (PE) & 0.629 \\
Attitude towards CT (A) & 0.842 \\
Behaviour Intention to Use (BI) & 0.840 \\
\hline
\end{tabular}

In order to test the hypothesis, Spearman's correlation test was conducted. The results are shown in Table 8.

Table 8: Summary of hypothesis testing

\begin{tabular}{lll}
\hline Hypothesis & Relationship & Correlation \\
\hline $\mathrm{H}_{1}$ & $\mathrm{PU} \rightarrow \mathrm{BI}$ & $0.389^{*}$ \\
$\mathrm{H}_{2}$ & $\mathrm{PE} \rightarrow \mathrm{BI}$ & $-0.146^{*}$ \\
$\mathrm{H}_{3}$ & $\mathrm{~A} \rightarrow \mathrm{BI}$ & $0.581^{* *}$ \\
\hline
\end{tabular}

${ }^{*} p<0.05 ;{ }^{* *} p<0.001$

The relationship between $\mathrm{PU}, \mathrm{PE}, \mathrm{A}$ and $\mathrm{BI}$ was tested using Spearman correlation. Based on the table, $\mathrm{PU} \rightarrow \mathrm{BI}(0.389)$ and $\mathrm{A} \rightarrow \mathrm{BI}(0.581)$ have a strong correlation. Since Perceived Usefulness of CT influence teachers' behaviour intention to use CT in teaching and learning ( $[r=0.389, n=294, p<0.001]$, therefore $H_{1}$ is accepted. Meanwhile, teachers' attitude toward CT influence the behaviour intention to use CT [r=0.581, $n=294, p<0.001]$, therefore $\mathrm{H}_{3}$ is accepted. In contrary, $\mathrm{PE} \rightarrow \mathrm{BI}$ showed a negative relationship with $\mathrm{r}=-0.146$. Therefore, $\mathrm{H}_{2}$ is rejected.

The finding reveals that perceived usefulness of using CT influenced teachers' behaviour intention to integrate CT in teaching and learning. Teachers' positive attitude towards CT showed a strong relationship with behaviour intention to use CT. These two significant correlations showed a positive feedback towards integrating CT among the teachers. Meanwhile, Perceived ease of use of CT have an inverse relationship on behaviour intention to integrate CT. This means the more teachers' perceived CT as a burden to workload, there is more likely they will not integrate CT in teaching and learning.

What are the misconceptions experienced by the teachers in integrating CT in teaching and learning?

69 respondents answered the open-ended question on the understanding on CT concepts. Table 9 summarised the themes emerged from the answers. The result revealed half of the answers from 69 respondents closely associate CT with technology. The themes were: CT involved using technology in teaching and learning, CT is teaching aid, CT involved using computer software, CT is solving problem using computer, and CT requires technology. Meanwhile the other half showed that respondent have good understanding of CT, in which they described: CT is a problem-solving technique, CT involved solving problem via computational approach, and CT involved thinking process and skills. 
Table 9: Summary of teachers' response on their understanding towards CT

\begin{tabular}{lc}
\hline Themes & Frequency \\
\hline CT involved using technology in teaching and learning & 11 \\
\hline CT is a problem-solving technique & 15 \\
\hline CT involved solving problem via computational approach & 13 \\
\hline CT is teaching aid & 4 \\
\hline CT involved using computer software & 4 \\
\hline CT involved thinking process and skills & 7 \\
\hline CT is solving problem using computer & 9 \\
\hline CT requires technology & 6 \\
\hline
\end{tabular}

It could be said that majority teachers still did not received enough training on CT after two years of CT implementation in the curriculum. This result is in line with Ling et al., (2017). Nevertheless, the open-ended questions result showed that half of the teachers do understand CT concept despite receiving less training on CT. Meanwhile the other half showed teachers still have misconceptions on how CT can be taught as most of them closely associate CT with technology, whilst CT can also be taught without using technology. With the misconceptions about the need of technology as an option to teach $\mathrm{CT}$, it might be one of the factors why some teachers viewing CT as another burden to bear in their daily task (Ling et al. 2017). Learning programming could be a daunting task especially for non-technical or non-STEM teachers, which explain the inverse relationship between teachers' Perceived ease of use and behaviour intention to integrate CT.

This raises concern on the method that have been informed to the teachers on how to integrate $\mathrm{CT}$ in teaching and learning. It is challenging for teachers either with or without computer background to comprehend since CT components are closely related to computer science concept (Alfayez \& Lambert, 2019) while the main idea to be instilled is actually on the thought process of solving problem using the components. On another note, it could be argued that by integrating CT via technology medium such as by using computer programming to learn CT might hinder one's awareness on the thought process of computational thinking while engaging with the programming activity. Rather, some might tend to focus more on getting the right output of the programming and driven away from the main objective which is to understand CT concepts and later transferring the knowledge and skills in different situation. This will not be the case if the teachers are provided with adequate support on CT knowledge and skills at early stage. This brings our attention to the need of shifting the focus of CT training. Rather than focusing on the in-service teacher, CT could be introduced to the pre-service teachers as early as during their training at teacher education institution. While CT can be taught through computer applications or plugged-ins (Lee \& Khalid, 2018; Nazir, Jano, \& Omar, 2019), perhaps it should be noted now that CT can also be taught using computer-free or unplugged methods.

\section{Conclusion}

Since teachers are agents of change in curriculum, effective steps need to be taken to prepare teachers to be well equipped with CT skills. Such effective preparation includes organizing structures training and post-training as a follow-up strategy to help teachers on how to develop knowledge and integrate CT concepts in teaching and learning. Besides that, supports 
should also be given to teachers in terms of pedagogical knowledge on CT emphasising on assessment and teaching materials to optimize teacher's role in the implementation of CT in Malaysia's education system. As much as the attention needs to be focused on instilling CT skills to the in-service teachers, it could also be suggested to channel the focus of delivering CT knowledge to the pre-service teacher, which will be the extension of this study.

\section{Acknowledgment}

This work was supported by UKM [Grant PP-FPEND-2019] and [Grant GG-2019-014]

\section{References}

Alfayez, A. A., \& Lambert, J. (2019). Exploring Saudi Computer Science Teachers' Conceptual Mastery Level of Computational Thinking Skills. Computers in the Schools. https://doi.org/10.1080/07380569.2019.1639593

Azman, S. M. S., Arsat, M., \& Mohamed, H. (2018). The framework for the integration of computational thinking in ideation process. In Proceedings of 2017 IEEE International Conference on Teaching, Assessment and Learning for Engineering, TALE 2017 (Vol. 2018-Janua, pp. 61-65). https://doi.org/10.1109/TALE.2017.8252305

Barr, V., \& Stephenson, C. (2011). Bringing computational thinking to K-12: What is involved and what is the role of the computer science education community? ACM Inroads, 2(1), 48-54. https://doi.org/10.1145/1929887.1929905

Basogain, X., Olabe, M. Á., Olabe, J. C., \& Rico, M. J. (2018). Computational Thinking in preuniversity Blended Learning classrooms. Computers in Human Behavior. https://doi.org/10.1016/j.chb.2017.04.058

Bennett, S., Maton, K., \& Kervin, L. (2008). The "digital natives" debate: A critical review of the evidence. British Journal of Educational Technology, 39(5), 775-786. https://doi.org/10.1111/j.1467-8535.2007.00793.x

Bower, M., Wood, L. N., Lai, J. W. M., Howe, C., \& Lister, R. (2017). Improving the computational thinking pedagogical capabilities of school teachers. Australian Journal of Teacher Education. https://doi.org/10.14221/ajte.2017v42n3.4

Brackmann, C. P., Román-González, M., Robles, G., Moreno-León, J., Casali, A., \& Barone, D. (2017). Development of Computational Thinking Skills through Unplugged Activities in Primary School. In Proceedings of the 12th Workshop on Primary and Secondary Computing Education - WiPSCE'17 (pp. 65-72). https://doi.org/10.1145/3137065.3137069

Chalmers, C. (2018). Robotics and computational thinking in primary school. International Journal of Child-Computer Interaction. https://doi.org/10.1016/j.ijcci.2018.06.005

Cheah, H. M. (2018). Computational Thinking Reshapes the Teachers' Perspective on Human Mind towards Teaching and Learning Process. In Proceedings of the International Conference on Computational Thinking Education 2018 (pp. 141-146). Hong Kong.

Conde, M. Á., Fernández-Llamas, C., Rodríguez-Sedano, F. J., Guerrero-Higueras, Á. M., Matellán-Olivera, V., \& García-Peñalvo, F. J. (2017). Promoting Computational Thinking in K-12 students by applying unplugged methods and robotics. In Proceedings of the 5th International Conference on Technological Ecosystems for Enhancing Multiculturality TEEM 2017 (pp. 1-6). https://doi.org/10.1145/3144826.3145355

Davis, F. D. (1989). Perceived usefulness, perceived ease of use, and user acceptance of information technology. MIS Quarterly: Management Information Systems, 319-340.

Denning, P. J. (2009). The profession of IT: Beyond computational thinking. Communications 
of the ACM, 52(6), 28-30. https://doi.org/10.1145/1516046.1516054

Di lorio, C. K. (2005). Measurement in health behaviour: methods for research evaluation.

Durodolu, O. (2016). Technology Acceptance Model as a predictor of using information system' to acquire information literacy skills. Library Philosophy and Practice.

Einhorn, S. (2012). Microworlds, computational thinking, and 21st century learning. LCSI White Paper.

Fessakis, G., Gouli, E., \& Mavroudi, E. (2013). Problem solving by 5-6 years old kindergarten children in a computer programming environment: A case study. Computers and Education, 63, 87-97. https://doi.org/10.1016/j.compedu.2012.11.016

Grover, S., \& Pea, R. (2013). Computational Thinking in K-12: A Review of the State of the Field. Educational Researcher, 42(1), 38-43.

https://doi.org/10.3102/0013189X12463051

Guzdial, M. (2008). Education: Paving the way for computational thinking. Communications of the ACM, 51(8), 25-27. https://doi.org/10.1145/1378704.1378713

Kafai, Y. B., \& Burke, Q. (2013). Computer Programming Goes Back to School. Phi Delta Kappan, 95(1), 61-65. https://doi.org/10.1177/003172171309500111

Kementerian Pendidikan Malaysia. (2014). Teknologi Maklumat dan Komunikasi Tahun Enam. Kementerian Pendidikan Malaysia, K. P. M. (2016). Kurikulum Standard Sekolah Rendah KSSR. Lee, I., Martin, F., Denner, J., Coulter, B., Allan, W., Erickson, J., ... Werner, L. (2011). Computational thinking for youth in practice. ACM Inroads, 2(1), 32-37. https://doi.org/10.1145/1929887.1929902

Lee, S. W., \& Khalid, F. (2018). Primary School Students' Experiences during Game Development Project Using Scratch. International Journal of Engineering \& Technology, 7(4.21), 16-19.

Ling, U. L., Saibin, T. C., Labadin, J., \& Aziz, N. A. (2017). Preliminary Investigation: Teachers' Perception on Computational Thinking Concepts. Journal of Telecommunication, Electronic and Computer Engineering, 9(2), 2289-8131.

Lu, J. J., \& Fletcher, G. H. L. (2009). Thinking about computational thinking. SIGCSE Bulletin Inroads. https://doi.org/10.1145/1539024.1508959

Nazir, F., Jano, Z., \& Omar, N. (2019). Algorithm as a problem solving technique for Teaching and learning of the malay language. Journal of Social Sciences and Humanities, 16(7), 112.

Rabah, K. (2016). The Future of Higher Educational Institutions (HEIs) in the Era of eLearning. Mara Research Journal of Information Science \& Technology.

Rahayu, T., \& Osman, K. (2019). Knowledge Level and Self-Confidence on The Computational Thinking Skills Among Science Teacher Candidates. Jurnal IImiah Pendidikan Fisika AlBiruni. https://doi.org/10.24042/jipfalbiruni.v8i1.4450

Richards, J. (2007). Computational thinking: a discipline with uses outside the computer lab? Computer Weekly.

Viadero, D. (2007). Center to Support Instruction on "Computational Thinking." Education, 26, 10.

Wing, J. M. (2006). Computational Thinking. Communications of the Association for Computing Machinery (ACM), 49(3), 33-35.

https://doi.org/https://www.cs.cmu.edu/ 15110-s13/Wing06-ct.pdf 